\title{
Effects of significant weight loss following bariatric surgery on red cell distribution width and mean platelet volume
}

\author{
Obezite cerrahisiyle etkin kilo vermenin kırmızı kan hücresi dağılım \\ genişliği ve ortalama trombosit hacmi üzerine etkisi
}

\author{
Cihan ALTIN ${ }^{1 \oplus,}$, Varlık EROL ${ }^{2} \oplus$, Mustafa YILMAZ ${ }^{3} \oplus$, Yusuf BOZKUŞ ${ }^{4} \odot$, Haldun MÜDERRISOĞLU $\odot$
}

\section{ABSTRACT}

Aim: Elevated red blood cell distribution width (RDW) and mean platelet volume (MPV) levels which are closely associated with chronic inflammation and platelet aggregation are suggested as independent predictors of obesity and cardiovascular diseases. However influence of significant weight loss following bariatric surgery on these parameters is unknown. Therefore we aimed to find out the effect of significant weight loss following laparoscopic sleeve gastrectomy (LSG) on RDW and MPV levels.

Methods: The medical data of 98 morbid obese subjects $(25$ male, 73 female) who were operated between February 2015 and June 2017 according to indications of bariatric surgery in current guidelines including body mass index $(B M I)>40 \mathrm{~kg} / \mathrm{m}^{2}$ or $B M l=35-40 \mathrm{~kg} /$ $\mathrm{m}^{2}$ with additional comorbidities were recorded. The difference between baseline and values at one year was expressed as a delta ( $\Delta)$.

Results: The mean age of our study population was $41.89 \pm 11.99$ years and mean weight loss in one year after LSG was $45.41 \pm 13.13$ $\mathrm{kg}(36.5 \%)$. BMI decreased from $46.60 \pm 7.11 \mathrm{~kg} / \mathrm{m}^{2}$ to $29.58 \pm 4.63$ $\mathrm{kg} / \mathrm{m}^{2}$. Compared to the baseline, significant decreases in RDW $(14.61 \pm 1.69 \%$ vs. $13.71 \pm 2.10 \% ; p<0.01)$ and MPV (8.63 \pm 1.45 vs. $7.92 \pm 1.24 f L, p<0.001$ ) levels were found in the postoperative oneyear values. In addition; $\triangle V K I$ was positively correlated with $\triangle R D W$ $(r=0.343, p<0.01)$ and $\triangle M P V(r=0.322, p<0.01)$.

Conclusion: We found that morbid obese subjects have significantly decreased RDW and MPV levels which are correlated to their weight loss in one-year follow-up after LSG. If we think that several factors may affect these parameters, conduction of further prospective large-scale studies are needed.

Keywords: Bariatric surgery, red blood cell distribution width, mean platelet volume, cardiovascular risk öz

\begin{abstract}
Amaç: Kronik inflamasyon ve trombosit agregasyonu ile yakından ilişkili olan artmış kırmızı kan hücresi dağılım genişliği (RDW) ve ortalama trombosit hacminin (MPV) obezite ve kardiyovasküler hastalıklar açısından birer bağımsız belirteç olduğu düşünülmektedir. Ancak obezite cerrahisi olup, belirgin kilo veren hastalarda bu parametrelerdeki değişim tam olarak bilinmemektedir. Bu çalışmada, laparoskopik sleeve gastrektomi (LSG) yapılan hastaların bir yılık takiplerinde RDW ve MPV değerlerindeki değişimi incelemeyi amaçladık.
\end{abstract}

Yöntem: Şubat 2015 ve Haziran 2017 tarihleri arasında LSG yapılan 98 morbid obez hastanın ( 73 kadın, 25 erkek) medikal kayıtlarını inceledik. Cerrahi endikasyonlar kılavuzlara uygun şekilde belirlendi; vücut kitle indeksi (VKi) $>40 \mathrm{~kg} / \mathrm{m}^{2}$ veya VKi>35 $\mathrm{kg} / \mathrm{m}^{2}$ ve birlikteliğinde obeziteyle ilişkili ek hastalıkların varlığı. Bazal değerler ile birinci yıldaki değerler arasındaki fark Delta $(\Delta)$ ile gösterildi.

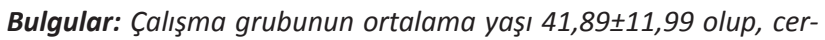

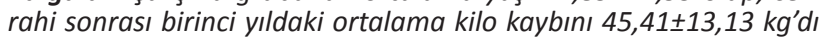

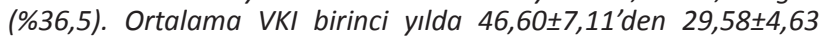

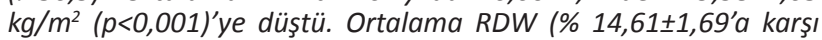
$\% 13,71 \pm 2,10 ; p<0,01)$ ve MPV $(8,63 \pm 1,45$ f'e karşı $7,92 \pm 1,24 \mathrm{fL}$, $p<0,001)$ seviyelerinde cerrahi sonrası anlamlı düşüş dikkati çekti. Ayrıca $\triangle$ VKI ile $\triangle R D W(r=0,343, p<0,01)$ ve $\triangle M P V(r=0,322$, $p<0,01)$ arasında pozitif korelasyon vardı.

Sonuç: LSG ile belirgin kilo veren hastaların birinci yıl takiplerinde verdikleri kilo ile korele olarak RDW ve MPV seviyelerinde anlamlı azalma bulduk. Ancak bu parametrelerin birçok faktörden etkilendiği düşünülecek olursa bu konuda prospektif, geniş ölçekli ileri çalışmalara gereksinim vardır.

Anahtar kelimeler: Bariatrik cerrahi, kırmızı kan hücresi dağılım genişliği, ortalama trombosit hacmi, kardiyovasküler risk

\footnotetext{
Received: 13.07.2018

Accepted: 02.10.2018

${ }^{1}$ Department of Cardiology, Baskent University, İzmir, Turkey

${ }^{2}$ Department of General Surgery, Baskent University, Izmir, Turkey

${ }^{3}$ Department of Cardiology, Baskent University, Adana, Turkey

${ }^{4}$ Department of Endocrinology, Baskent University, Ankara, Turkey

${ }^{5}$ Department of Cardiology, Baskent University, Ankara, Turkey

Corresponding author: Cihan Altın, Department of Cardiology, Başkent University, İzmir, Turkey

e-mail: drcihanaltin@hotmail.com
}

ORCID ID's:

C.A. 0000-0002-3996-5681, V.E. 0000-0002-7337-4973, M.Y. 0000-0002-2557-9579, Y.B. 0000-0002-6976-6659, H.M. 0000-0002-9635-6313 


\section{GiRiş}

Obezite özellikle gelişmiş ülkeler başta olmak üzere prevalansı giderek artan, dünya ekonomisi üzerinde ciddi yük oluşturan, çeşitli yandaş sorunlara yol açan önemli bir halk sağlığı sorunudur. Obezite ile mücadelede diyet, egzersiz programları ve çeşitli farmakolojik ajanlar kullanılıyor olsa da genellikle sonuçlar çok yüz güldürücü değildir. İşte bütün bu yöntemler başarısız olduğunda bariatrik cerrahi yöntemleri gündeme gelmektedir. "Tüp mide" olarak da adlandırılan laparoskopik sleeve gastrektomi (LSG) gerek daha basit bir işlem olması gerekse de düşük komplikasyon oranlarına sahip olması nedeniyle günümüzde oldukça sık yeğlenen bir bariatrik cerrahi yöntemidir ${ }^{1,2}$.

Morbid obezitede artmış mortalite ve morbiditenin başlıca nedeni kardiyovasküler hastalıklardır (KVH)². Mortalite oranlarını düşürebilmek için obez bireylerin erken dönemde $\mathrm{KVH}$ açısından risklerinin belirlenip, yüksek riskli bireylerde gerekli önlemlerin alınması gerekmektedir. Kardiyovasküler risk değerlendirilmesinde kullanılan geleneksel yöntemlerin dışında bize ek bilgiler sunacak yeni, pratik, güvenilir, ucuz ve girişimsel olmayan yöntemlere gereksinim duyulmaktadır.

Kronik inflamasyon ve platelet aktivasyonunun $\mathrm{KVH}^{\prime \prime}$ ın patogenezinde yer aldığı bilinmektedir ${ }^{3,4}$. Kırmızı kan hücresi dağılım genişliği (RDW) ve ortalama trombosit hacmi (MPV) kolaylıkla ölçülebilen ve düşük maliyetli tam kan sayımı parametreleridir. Kronik inflamasyon 5 ve platelet agregasyonu 4 ile yakından ilişkisi olan bu iki parametrenin son zamanlarda obezite ve KVH açısından birer bağımsız belirteç olduğu gösterilmiştir ${ }^{6-12}$. Ancak obezite cerrahisi olup, belirgin kilo veren hastalarda bu parametrelerdeki değişim tam olarak bilinmemektedir. Biz bu çalışmada, LSG operasyonu geçiren hastaların bir yıllık takiplerinde RDW ve MPV değerlerindeki değişimi incelemeyi amaçladık.

\section{GEREÇ ve YÖNTEM}

Şubat 2015-Haziran 2017 tarihleri arasında kliniği- mizde uygun endikasyonlar dahilinde obezite cerrahisi olarak LSG yapılan hastalar çalışmaya dahil edildi. Cerrahi endikasyonlar kılavuzlara 1 uygun şekilde belirlendi; vücut kitle indeksi (VKi) $>40 \mathrm{~kg} / \mathrm{m}^{2}$ veya VKi $35-40 \mathrm{~kg} / \mathrm{m}^{2}$ ve birlikteliğinde obezite ile ilişkili ek hastalıkların olması (hipertansiyon, diyabetes mellitus, hiperlipidemi, obstrüktif uyku apne sendromu gibi), ayrıca hastalarda cerrahi dışı diyet, egzersiz ve medikal tedavi gibi yöntemlerin denenmiş ve başarısız olmuş olması ve yine ciddi mental veya psikiyatrik bozuklukların ve yüksek cerrahi riskinin olmaması.

Bilinen koroner arter hastalığı (KAH) (koroner anjiyografi ile dökümente edilmiş, girişim yapılmış veya opere edilmiş koroner darlıklar), kontrolsüz ciddi diyabeti, hematolojik hastalığı, kanseri, aktif enfeksiyonu, sistemik inflamatuvar hastalığı, alkol veya ilaç bağımlılığı, yeme bozukluğu, majör depresyon ve psikozu da içeren psikiyatrik veya mental hastalığı, kalp, böbrek veya karaciğer yetersizliği olan bireyler dışlandı.

Onam formu alınıp çalışmaya dahil edilen hastaların klinik, demografik verileri, antropometrik özellikleri, risk faktörleri, sol ventrikül ejeksiyon fraksiyonları (EF) ve açlık kan örneklerinden çalışılan RDW ve MPV değerlerini de içeren çeşitli hematolojik ve biyokimyasal parametreleri kaydedildi. Cerrahi sonrası birinci yılda benzer verilere yine bakılıp bu veriler ameliyat öncesi verilerle kıyaslandı. Bazal değerler ile birinci yıldaki değerler arasındaki fark Delta $(\Delta)$ ile gösterildi. $(\operatorname{Delta}(\Delta)=$ Bazal veri - birinci yıldaki veri)

Bu çalışma Başkent Üniversitesi Tıp ve Sağlık Bilimleri Araştırma Kurulu tarafından onaylanıp (Proje no: KA18/232) Başkent Üniversitesi Araştırma Fonunca desteklendi.

\section{Kırmızı hücre dağılım genişliği (RDW) ve ortalama trombosit hacmi (MPV) ölçümü}

Kan örnekleri 12 saatlik açlığı takiben alındı. RDW ve MPV seviyeleri otomatik kan analizörleri ile ölçüldü. (Cell-Dyn 3700 system; Abbott Diagnostics, Inc., Santa Clara, CA, USA). 


\section{Laparoskopik Sleeve Gastrektomi (LSG)}

Cerrahi aletlerin geçişini sağlamak amacıyla toplamda 5 adet trokar (bir adet $15 \mathrm{~mm}$, iki $12 \mathrm{~mm}$ ve iki adet $5 \mathrm{~mm}$ çapında) kullanıldı. Otuz derece açılı laparoskopik kamera port boyunca periton boşluğuna yerleştirildi. Ksifoid altındaki $5 \mathrm{~mm}$ çapındaki trokar çıkartılarak otomatik karaciğer ekartörü yerleştirildi ve mideye daha rahat ulaşabilmek için karaciğer sol lobu ekarte edildi. Mide büyük kurvatur tarafı pilordan 2-4 cm proksimalden başlanarak HIS açısına kadar omentumdan ve kısa gastrik damarlardan laparoskopik olarak serbestlendi. Geniş bir fundik poştan kaçınmak için proksimal mide posterior bölümünün diseksiyonu titizlikle yapıldı. Mide küçük kurvatur tarafına $32 \mathrm{~F}$ kalınlığında dilatasyon tüpü yerleştirildi. Mide, antrumda iki adet 4,5 mm'lik endoskopik lineer kesici zımba kullanılarak ve daha proksimal kısımlarda 3,8 mm'lik staplerler yardımıyla (Staples; Medtronic, Minnesota, ABD) rezeke edildi. Stapler hattından kanamalar laparoskopik klipsler kullanılarak kontrol altında alındı. Geri kalan tüp şekilli mide boyunca bulunan stapler hattı, operasyon bölgesi serum fizyolojik ile doldurulduktan sonra mide nazogastrik sonda yardımıyla hava ile şişirilerek kaçak varlığı açısından test edildi. Rezeke edilen mide 15 $\mathrm{mm}$ trokar giriş insizyonundan karın dışına çıkarıldı. Trokar giriş yerindeki faysa defektleri emilemeyen sütürlerle kapatıldı.

\section{İstatistiksel analiz}

Tüm veriler SPPS 20 (IBM Corp. Released 2011. IBM SPSS Statistics for Windows, Version 20,0. Armonk, NY: IBM Corp.) istatistik programı ile değerlendirildi. Varyansların homojenliği "Levene" testi ile değerlendirildi. Ölçülebilen değişkenlerin normal dağılıma uygunluğu Kolmogorov-Smirnov ile test edildi. Tanıtıcı istatistikler ortalama \pm standart sapma veya medyan (Maksimum-Minumum) olarak verildi. Kategorik değişkenler ise yüzde ve frekans değerleri olarak gösterildi. Parametrik test ön şartları sağlandığında eşli $t$ testi (paired t test), sağlamadığında ise Wilcoxon testi kullanıldı. iliş̧kilerin belirlenmesi için yapılan istatistik analizinde iki sürekli değişken arasındaki ilişki- ler parametrik test ön şartları sağladığında Pearson, sağlamadığında ise spearman korelasyon katsayısı ile gösterildi. İstatistiksel olarak $p$ değeri $<0,05$ anlamlı kabul edildi.

\section{BULGULAR}

Toplamda 124 hasta çalışmaya dahil edildi. Ancak bunlardan 11 'i yüksek cerrahi risk veya hastanın vazgeçmesi nedeniyle ameliyat edilmedi. Geri kalan 113 hastanın 15 'i operasyon sonrası birinci yıl kontrolüne gelmemesi nedeniyle çalışma dışı bırakıldı. Geriye kalan 98 (73 kadın ve 25 erkek, ortalama yaşı $41,89 \pm 11,99)$ hastanın analizi yapıldı.

Hastaların bazal demografik ve klinik özellikleri Tablo 1 'de verilmektedir. Cerrahi öncesi ve sonrası birinci yılda klinik, antropometrik, RDW ve MPV değerlerini de içeren bazı hematolojik ve biyokimyasal parametreler Tablo 2'de gösterilmektedir.

Tablo 1. Çalışma popülasyonuna ait bazal demografik, antropometrik ve klinik veriler.

\begin{tabular}{ll}
\hline & $\mathbf{n = 9 8}$ \\
\hline Yaş (yıl) & $41,89 \pm 11,99$ \\
Kilo (kg) & $124,42 \pm 13,13$ \\
Boy (cm) & $163,32 \pm 9,25$ \\
Erkek, n (\%) & $25(25,6)$ \\
Hipertansiyon, n (\%) & $43(43,9)$ \\
Diyabet, n (\%) & $22(22,4)$ \\
Hiperlipidemi, $\mathrm{n}(\%)$ & $69(70,4)$ \\
Sigara, $\mathrm{n}(\%)$ & $33(33,7)$ \\
Ailede koroner arter hastalığı, n (\%) & $42(42,9)$ \\
\hline
\end{tabular}

Cerrahi sonrası birinci yıldaki ortalama kilo kaybı $45,41 \pm 13,13 \mathrm{~kg}$ 'dı $(\% 36,5)$. Ortalama VKI birinci yılda $46,60 \pm 7,11 \mathrm{~kg} / \mathrm{m}^{2 \prime}$ den $29,58 \pm 4,63 \mathrm{~kg} / \mathrm{m}^{2}$ $(p<0,001)^{\prime} y e$ düştü. Sol ventrikül EF'sinde cerrahi öncesi ve sonrası anlamlı farklılık yoktu. Ortalama RDW

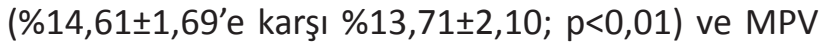
$(8,63 \pm 1,45$ f'e karşı 7,92 $\pm 1,24 \mathrm{fL}, \mathrm{p}<0,001)$ seviyelerinde cerrahi sonrası birinci yılda anlamlı düşüş dikkati çekti (Figür 1). Yapılan korelasyon analizinde; $\Delta$ VKI ile $\Delta$ RDW $(r=0,343, p<0,01)$ ve $\Delta$ MPV $(r=0,322$, $p<0,01$ ) arasında anlamlı pozitif korelasyon vardı (Figür 2, Tablo 3). 
Tablo 2. Operasyon sonrası birinci yılda demografik, klinik, antropometrik ve biyokimyasal verilerdeki değişim.

\begin{tabular}{|c|c|c|c|}
\hline & Operasyon öncesi & Operasyon sonrası (1. yıl) & P değeri \\
\hline Vücut kitle indeksi (kg/m²) & $46,60 \pm 7,11$ & $29,58 \pm 4,63$ & $<0,001$ \\
\hline Sistolik kan basıncı (mmHg) & $139,95 \pm 21,76$ & $132,30 \pm 15,33$ & $<0,001$ \\
\hline Diyastolik kan basıncı (mmHg) & $83,98 \pm 13,98$ & $81,07 \pm 10,61$ & $<0,001$ \\
\hline Kalp hızı (atım/dk.) & $75,44 \pm 12,23$ & $72,58 \pm 11,56$ & 0,090 \\
\hline Ejeksiyon fraksiyonu (\%) & $59,61 \pm 4,46$ & $59,88 \pm 4,25$ & 0,060 \\
\hline \multicolumn{4}{|l|}{ Laboratuvar verileri } \\
\hline Açlık glukozu (mg/dl) & $122,18 \pm 35,41$ & $92,79 \pm 15,02$ & $<0,001$ \\
\hline Açlık insülin ( $\mu \mathrm{IU} / \mathrm{ml})$ & $26,88 \pm 17,47$ & $7,16 \pm 3,64$ & $<0,001$ \\
\hline HOMA-IR indeksi & $8,51 \pm 7,68$ & $1,66 \pm 0,93$ & $<0,001$ \\
\hline LDL-K ( (mg/dl) & $145,03 \pm 37,24$ & $124,75 \pm 34,00$ & $<0,001$ \\
\hline HDL-K ( (mg/dl) & $46,83 \pm 9,40$ & $50,58 \pm 9,55$ & $<0,001$ \\
\hline Trigliserid (mg/dl) & $124,30 \pm 60,47$ & $109,88 \pm 50,95$ & $<0,05$ \\
\hline Kreatinin (mg/dl) & $0,74 \pm 0,11$ & $0,72 \pm 0,10$ & 0,918 \\
\hline ALT $(U / L)$ & $29,05 \pm 12,80$ & $21,87 \pm 8,81$ & $<0,001$ \\
\hline $\operatorname{CRP}(\mathrm{mg} / \mathrm{dl})$ & $0,56 \pm 0,65$ & $0,37 \pm 0,53$ & $<0,05$ \\
\hline Hemoglobin (g/dL) & $13,67 \pm 1,12$ & $13,84 \pm 1,22$ & 0,418 \\
\hline Lökosit (bin $/ \mu \mathrm{L})$ & $7,52 \pm 1,68$ & $7,51 \pm 1,70$ & 0,636 \\
\hline Trombosit $(\mathrm{K} / \mu \mathrm{L})$ & $269,42 \pm 51,60$ & $248,49 \pm 49,41$ & 0,001 \\
\hline RDW (\%) & $14,61 \pm 1,69$ & $13,71 \pm 2,10$ & $<0,01$ \\
\hline MPV (fL) & $8,63 \pm 1,45$ & $7,92 \pm 1,24$ & $<0,001$ \\
\hline
\end{tabular}

ALT: Alanin transaminaz, CRP: C-reaktif protein, HDL-K: High-density lipoprotein kolesterol, LDL-K: Low-density lipoprotein kolesterol, RDW: Red blood cell distribution width, MPV: Mean platelet volume.

Tablo 3. Delta $(\Delta)$ vücut kitle indeksi ile çeşitli değişkenler arasındaki korelasyon analizi.

\begin{tabular}{lll}
\hline Değişkenler & $r$ & P değeri \\
\hline$\Delta$ RDW & 0,343 & $<0,01$ \\
$\Delta$ MPV & 0,322 & $<0,01$ \\
$\Delta$ Trombosit sayısı & 0,112 & 0,274 \\
$\Delta$ CRP & 0,170 & 0,095
\end{tabular}

CRP: C-reaktif protein, RDW: Red blood cell distribution width, MPV: Mean platelet volume.
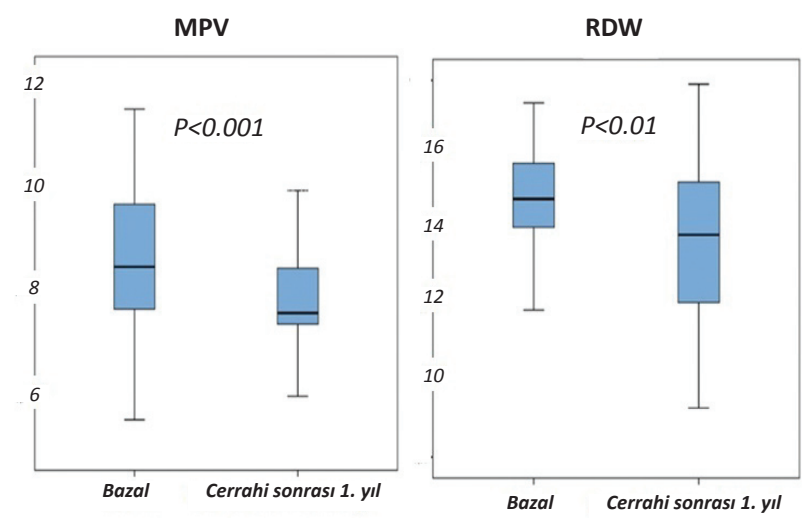

Figür 1. Bariatrik cerrahi öncesi ve sonrası birinci yıldaki kırmızı kan hücresi dağılım genişliği (RDW) ve ortalama trombosit hacmi (MPV) değerleri.

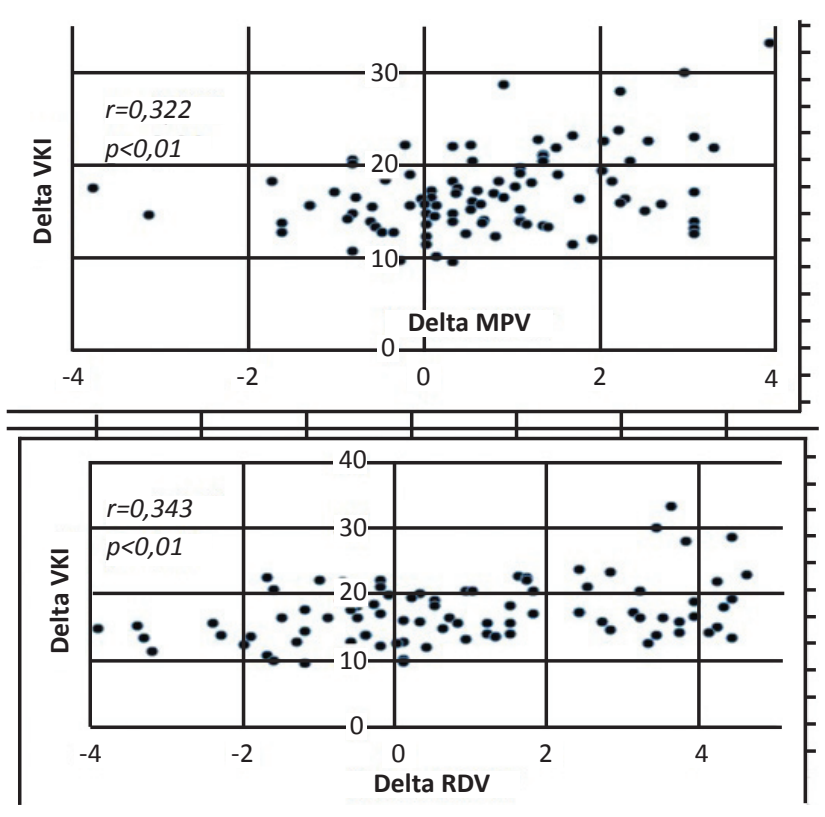

Figür 2. Delta vücut kitle indeksi (VKI) ile delta kırmızı kan hücresi dağılım genişliği (RDW) ve delta ortalama trombosit hacmi (MPV) arasındaki anlamlı pozitif korelasyonu gösteren saçılım grafiği. 


\section{TARTIŞMA}

Obezite ile ilişkili mortalitenin düşürülmesinde $K A H^{\prime} ı n$ erken tanı ve tedavisinin önemi inkar edilemez. KAH açısından daha riskli bireylerin erken dönemde yakalanabilmesi için bilinen geleneksel risk faktörlerinin yanı sıra bize ek bilgi sağlayacak yeni belirteçlere gereksinim duyulmaktadır. Kronik inflamasyon ve platelet agregasyonu ile yakında ilişkili olan RDW ve MPV'nin aterosklerotik süreç ve miyokard iskemisi hakkında bilgi sağlayabilecek ucuz, pratik ve kolay ulaşılabilir parametreler olabileceği gösterilmiştir ${ }^{7-11}$.

Aneminin ayırıcı tanısında kullanılan RDW "eritrositlerin boyutlarındaki değişimi yansıtan" bir tam kan sayımı parametresi olup, aynı zamanda kronik inflamasyonun iyi bir belirtecidir. Kanser, otoimmun ve romatolojik hastalıklar gibi inflamatuvar durumlarda arttığı bilinmektedir. Yapılan çalışmalarda, RDW'nin stabil 7 ve stabil olmayan $8 \mathrm{KAH}$ varlığında artmış mortalite ve olumsuz kardiyovasküler olaylar ile ilişkisi gösterilmiştir. Akut koroner sendromda yüksek RDW ile ölüm ve 6 ay içinde yine miyokard enfarktüsü arasında bağımsız bir korelasyon saptanmıştır. Geniş bir kohort analizinde de RDW ile koroner anjiyografi ile saptanan $\mathrm{KAH}$ ve KAH'ın ciddiyeti arasında anlamlı ilişki ve korelasyon bulunmuştur ${ }^{17}$. Benzer şekilde koroner bilgisayarlı tomografik anjiyografi ile saptanan KAH ile RDW arasında da anlamlı bir ilişki raporlanmıştır ${ }^{18}$. Bunun dışında, periferik arter hastalığı, diyabet, kronik akciğer hastalığı ve perkütan koroner girişim yapılan hastalarda, böbrek ve kalp yetmezliğinde de kötü prognozun bir göstergesi olduğu rapor edilmiştir ${ }^{19,20}$.

Obezitenin kronik inflamatuvar süreçle yakın ilişkisi bilinmektedir $^{6}$. Bu nedenle RDW ile obezitenin ilişkisini tahmin etmek güç değildir. Ancak obezite cerrahisi sonrası belirgin kilo veren hastalardaki RDW'nin değişimini inceleyen yeterli literatür yoktur. Çalışmamızda, obezite cerrahisi ile anlamlı kilo veren bireylerin birinci yıl kontrolünde RDW'de anlamlı azalma saptadık. Wise ve ark. ${ }^{21}$ bariatrik cerrahi sonrası 1. yılda RDW'nin fazla VKI kaybının bir göstergesi olduğunu raporlamışlardır. Rocha ve ark. ${ }^{22}$ obezite cerra- hisi geçiren kadınlarda 8. haftada ölçülen glukoz, lipid parametreleri ve hemoglobin seviyelerinde azalmayla beraber RDW değerlerinde artış raporlamışlardır. Bu durum cerrahi sonrası ilk haftalarda görülen beslenme bozukluğu ve demir eksikliği ile ilişkili olabilir. Uygun mineral ve vitamin takviyeleri ile ilk dönemler atlatıldıktan sonra kronik inflamatuvar süreç baskılanıp RDW değerleri de azalıyor olabilir.

Bir diğer tam kan sayımı parametresi olan MPV ise "ortalama trombosit boyutunu" göstermektedir. Büyük trombosit hacmini yansıtan artmış MPV'nin, artmış trombosit aktivasyonu ve miyokard enfarktüsünü gösteren bir belirteç olduğu düşünülmektedir ${ }^{4}$. KAH dışında diğer aterosklerotik hastalıklar, kalp yetmezliği, hipertansiyon, hiperlipidemi, diyabetes mellitus ve kronik böbrek yetmezliği varlığında da artabileceği belirtilmiştir ${ }^{23-25}$.

Çalışmamızda, obezite cerrahisi sonrası birinci yıl kontrolünde MPV'de anlamlı azalma saptadık ve bu azalmanın VKI'daki azalma ile korele olduğunu gösterdik. Coban ve ark. ${ }^{26}$ da bizim çalışmamıza benzer şekilde uygun diyet programlarıla zayıflayan obez hastalarda MPV'nin de anlamlı bir şekilde azaldığını raporlamışlardır. Ancak bu konuda çelişkili yayınlar da vardır. Kutlucan ve ark. ${ }^{27}$ metabolik sendromlu hastalarda obezite ile MPV arasında bir ilişki bulamamışlardır. Raoux ve ark. ${ }^{28}$ ise bariatrik cerrahi sonrası MPV değerlerinde anlamlı bir değişiklik bulmamışlardır. Kutluturk ve ark. ${ }^{29}$ ise bizim çalışmamızın aksine bariatrik cerrahi sonrası 6. ayda platelet sayısında azalmayla beraber MPV seviyelerinde artış raporlamışlardır. Bariatrik cerrahi sonrası erken dönemde MPV artmış olsa da uzun dönemde kronik inflamasyon yatışınca yine azalmış olabileceğini düşünüyoruz.

Obezite ve aterosklerotik hastalıklar ile artmış RDW ve MPV değerlerinin arasındaki ilişki net olarak anlaşılamamıştır. Birçok hipotez öne sürülmekle birlikte, en çok altta yatan kronik inflamatuvar süreç üzerinde durulmaktadır. Gerek obezitenin ve gerekse aterosklerotik hastalıkların ortak patogenezinde kronik inflamatuvar sürecin yer aldığı bilinmektedir ${ }^{3,6,30}$. İnflamatuvar sitokinlerin ateroskleroz patogenezindeki 
rolünün yanı sıra kemik iliği ve hematopoez üzerine de etkisi olabilir ${ }^{5}$. LSG sonrası ghrelin ve leptindeki gibi adipositokinlerdeki dramatik azalmanın da hematopoetik sistemi etkileyerek MPV ve RDW değerlerini değiştirebileceği de düşünülmektedir ${ }^{31,32}$.

DeAquino ve ark.'ın ${ }^{32}$ sınıflamasına göre, bariatrik cerrahi sonrası hastaların kilolarının \% 25'inden fazlasını vermesi işlemin başarılı, \%30'undan fazlasını vermesi ise çok başarılı olduğunu göstermektedir. Çalışmamızda hastalar kilolarının \%35'inden fazlasını vermiş olup, bu sınıflamaya göre cerrahi amacına ulaşmış ve çok başarılı sonuçlanmıştır.

Obezite cerrahisi sonrası etkin kilo vermekle birçok metabolik parametrenin düzelip, hastaların prognozunun olumlu yönde etkilendiği bilinmektedir². Çalışmamızda, LSG ile belirgin kilo veren hastaların birinci yıl takiplerinde verdikleri kilo ile korele olarak RDW ve MPV seviyelerinde anlamlı azalma bulduk. Bu durum da bu hasta grubunda etkin kilo kaybının sistemik kronik inflamatuvar yanıt ve platelet aktivasyonu üzerine olumlu etkisinin olabileceğini akla getirmektedir. Çalışmamız bu durumu ve patogenezi açıklayabilecek nitelikte olmayıp bu konuda kesin yorumlar yapabilmek için ileri çalışmalar gerekmektedir.

\section{Kısıtlılıklar}

Kısa takip süresi ve nispeten küçük ölçekli bir çalışma olması en önemli kısıtıııklardandır. Ayrıca çalışma popülasyonumuz tamamen homojen olmayıp, bu sonuçların tüm topluma genellenmesi doğru değildir. Bir kontrol grubunun olmaması da çalışmanın diğer bir kısıtlılığıdır. Ayrıca olanak kısıtlıığı nedeniyle yüksek duyarlılıklı CRP, tümör nekroz faktör- $\alpha$ veya interlökin seviyeleri gibi inflamasyonun hassas belirteçleri ölçülememiştir. RDW ve MPV'nin hastaların komorbid durumlarından, kullandıkları ilaçlardan, beslenme dengesinden, serum vitamin B12, folik asit ve ferritin, demir seviyesini de içeren birçok faktörden de etkilenebileceği düşünülürse bu konuyla ilgili geniş kapsamlı ileri prospektif çalışmalara gereksinim duyulmaktadır.

\section{KAYNAKLAR}

1. Fried M, Yumuk V, Oppert JM, et al. International Federation for Surgery of obesity and metabolic disorders-European chapter (IFSO-EC); European Association for the Study of obesity (EASO); European Association for the Study of Obesity Obesity Management Task Force (EASO OMTF). Interdisciplinary European guidelines on metabolic and bariatric surgery. Obes Surg. 2014;24(1):42-55. https://doi.org/10.1007/s11695-013-1079-8

2. Tromba L, Tartaglia F, Carbotta S, et al. The Role of Sleeve Gastrectomy in Reducing Cardiovascular Risk. Obes Surg. 2017;27(5):1145-51.

https://doi.org/10.1007/s11695-016-2441-4

3. Drakopoulou M, Toutouzas K, Stefanadi E, et al. Association of inflammatory markers with angiographic severity and extent of coronary artery disease. Atherosclerosis. 2009;206:335-9. https://doi.org/10.1016/j.atherosclerosis.2009.01.041

4. Park Y, Schoene N, Harris W. Mean platelet volume as an indicator of platelet activation: methodological issues. Platelets. 2002;13:301-6.

https://doi.org/10.1080/095371002220148332

5. Lippi G, Targher G, Montagnana M, et al. Relation between red blood cell distribution width and inflammatory biomarkers in a large cohort of unselected outpatients. Arch Pathol Lab Med. 2009;133:628-32.

6. Fujita B, Strodthoff D, Fritzenwanger $M$, et al. Altered red blood cell distribution width in overweight adolescents and its association with markers of inflammation. Pediatric Obesity. 2013;(5):385-91. https://doi.org/10.1111/j.2047-6310.2012.00111.x

7. Tonelli M, Sacks F, Arnold M, et al. Relation Between Red Blood Cell Distribution Width and Cardiovascular Event Rate in People With Coronary Disease. Circulation. 2008;117:163-8. https://doi.org/10.1161/CIRCULATIONAHA.107.727545

8. Nabais S, Losa N, Gaspar A, et al. Association between red blood cell distribution width and outcomes at six months in patients with acute coronary syndromes. Rev Port Cardiol. 2009;28:905-24.

9. Vizioli L, Muscari S, Muscari A. The relationship of mean platelet volume with the risk and prognosis of cardiovascular diseases. Int J Clin Pract. 2009;63:1509-15. https://doi.org/10.1111/j.1742-1241.2009.02070.x

10. Chu SG, Becker RC, Berger PB, et al. Mean platelet volume as a predictor of cardiovascular risk: a systematic review and meta-analysis. J Thromb Haemost. 2010;8:148-56. https://doi.org/10.1111/j.1538-7836.2009.03584.x

11. Murat SN, Duran M, Kalay N, et al. Relation between mean platelet volume and severity of atherosclerosis in patients with acute coronary syndromes. Angiology. 2013;64:131-6. https://doi.org/10.1177/0003319711436247

12. Coban E, Ozdogan M, Yazicioglu G, Akcit F. The mean platelet volume in patients with obesity. Int J Clin Pract. 2005;59:981-2.

https://doi.org/10.1111/j.1742-1241.2005.00500.x

13. Atila K. Morbid obezitenin cerrahi tedavisi. Archives of Clinical Toxicology 2014;1:23-7.

14. Sanchez SR, Masdevall C, Baltasar A, et al. Short and Midterm Outcomes of Sleeve Gastrectomy for Morbid Obesity: The Experience of the Spanish National Registry. Obes Surg. 2009;19:1203-10. https://doi.org/10.1007/s11695-009-9892-9

15. Menenakos E, Stamou K, Albanopoulos K, et al. Laparoscopic 
Sleeve Gastrectomy Performed with Intent to Treat Morbid Obesity: A Prospective Single-Center Study of 261 Patients with a Median Follow-up of 1 Year. Obes Surg. 2010; 20:27682.

https://doi.org/10.1007/s11695-009-9918-3

16. Noah J, Smith A, Birch D, Karmali S. The Metabolic Effects of Laparoscopic Sleeve Gastrectomy: A Review. J Minim Invasive Surg Sci. 2013;2(3):3-7.

17. Ma FL, Li S, Li XL, et al. Correlation of red cell distribution width with the severity of coronary artery disease: a large Chinese cohort study from a single center.Chin Med J. 2013;126:1053-7.

18. Karaçağlar E, Bal U, Hasırcı S, et al. Coronary artery disease detected by coronary computed tomography angiography is associated with red cell distribution width. Turk Kardiyol Dern Ars. 2016 Oct;44(7):570-4. https://doi.org/10.5543/tkda.2016.45013

19. Poludasu S, Marmur JD, Weedon J, et al. Red cell distribution width (RDW) as a predictor of long-term mortality in patients undergoing percutaneous coronary intervention. Thrombosis and Haemostasis. 2009;102(3):581-7. https://doi.org/10.1160/TH09-02-0127

20. Bujak K, Wasilewski J, Osadnik T, et al. The Prognostic role of red blood cell distribution width in coronary artery disease: A Review of the Pathophysiology. Disease Markers. 2015; 2015:824624. https://doi.org/10.1155/2015/824624

21. Wise ES, Hocking KM, Weltz A, et al. Red cell distribution width is a novel biomarker that predicts excess body-mass index loss 1 year after laparoscopic Roux-en-Y gastric bypass. Surg Endosc. 2016 Oct;30(10):4607-12. https://doi.org/10.1007/s00464-016-4798-9

22. Rocha VC, de Arvelos LR, Felix GP, et al. Evolution of nutritional, hematologic and biochemical changes in obese women during 8 weeks after Roux-en-Y gastric bypasss. Nutr Hosp. 2012;27(4):1134-40.

23. Papanas N, Symeonidis G, Maltezos E, et al. Mean platelet volume in patients with type 2 diabetes mellitus. Platelets. 2004;15:475-8. https://doi.org/10.1080/0953710042000267707

24. Karabacak M, Dogan A, Turkdogan AK, et al. Mean platelet volume is increased in patients with hypertensive crises. Platelets. 2014;25:423-6. https://doi.org/10.3109/09537104.2013.830181

25. Erne P, Wardle J, Sanders K, et al. Mean platelet volume and size distribution and their sensitivity to agonist in patients with coronary artery disease and congestive heart failure. Thromb Haemostas. 1988;59:259-63. https://doi.org/10.1055/s-0038-1642766

26. Coban E, Yilmaz A, Sari R. The effect of weight loss on the mean platelet volume in obese patients. Platelets. 2007;18(3):212-6. https://doi.org/10.1080/09537100600975362

27. Kutlucan A, Bulur S, Kr S, et al. The relationship between mean platelet volume with metabolic syndrome in obese individuals. Blood Coagul Fibrinolysis. 2012;23(5):388-90. https://doi.org/10.1097/MBC.0b013e328352e8fa

28. Raoux L, Moszkowicz D, Vychnevskaia K, et al. Effect of bariatric surgery-induced weight loss on platelet count and mean platelet volume: a 12-month follow-up study. Obes Surg. 2017;27(2):387-93. https://doi.org/10.1007/s11695-016-2292-z

29. Kutluturk F, Ozsoy Z. Effect of sleeve gastrectomy on platelet counts and mean platelet volumes. Obes Surg. 2018 May 1. https://doi.org/10.1007/s11695-018-3287-8

30. Drakopoulou M, Toutouzas K, Stefanadi E, et al. Association of inflammatory markers with angiographic severity and extent of coronary artery disease. Atherosclerosis. 2009;206:335-9. https://doi.org/10.1016/j.atherosclerosis.2009.01.041

31. Woelnerhanssen B, Peterli R, Steinert RE, et al. Effects of postbariatric surgery weight loss on adipokines and metabolic parameters: comparison of laparoscopicRoux-en-Y gastric bypass and laparoscopic sleeve gastrectomy-a prospective randomized trial. Surg Obes Relat Dis Off J Am Soc Bariatr Surg. 2011;7(5):561-8. https://doi.org/10.1016/j.soard.2011.01.044

32. Anfossi G, Russo I, Doronzo G, Pomero A, Trovati M. Adipocytokines in atherothrombosis: focus on platelets and vascular smooth muscle cells. Mediators Inflamm. 2010;2010:174341. https://doi.org/10.1155/2010/174341

33. DeAquino LA, Pereira SE, de Souza Silva J. Bariatric surgery: impact on body composition after Roux-en-Y gastric bypass. Obes Surg. 2012;22:195-200. https://doi.org/10.1007/s11695-011-0500-4 